\title{
A INFLUÊNCIA DE JOHN DEWEY NO ENSINO E FORMAÇÃO DO PROFESSORADO DE INGLÊS NA ARGENTINA
}

\author{
Gabriela Andrea Llaneza ${ }^{1}$ \\ (1) $\underline{\text { https://orcid.org/0000-0003-0410-2648 }}$ \\ Marisa Zelaya ${ }^{2}$ \\ (1Dhttps://orcid.org/0000-0003-2955-1925
}

Resumo: Neste breve trabalho serão identificadas as características da filosofia pedagógica deweyana em relação ao papel da experiência na aprendizagem, à construção social da linguagem e à importância da experimentação nos processos de aprendizagem para uma educação emancipatória e participativa. Na Argentina as contribuições do filósofo estadunidense incidiram de maneira tendenciosa e fragmentada, no entanto, as instituições educativas próximas ao setor privado resultaram permeáveis à filosofia pragmática-experimental. Tais instituições privadas e colégios bilíngues têm marcado tendência no ensino de inglês como língua estrangeira ao aplicar a abordagem comunicativa, a qual harmoniza princípios do construtivismo social, propostos por Jerome Bruner, e da linguística sistêmico-funcional (SFL), difundida por M.A.K. Halliday; e ao promover competências sócio-pragmáticas para a interação multicultural. Como parte da atualização dos desenhos curriculares em 1994-1995, 2007 e 2018, foi adotada a abordagem comunicativa como metodologia não só no ensino de inglês como língua estrangeira, mas também no desenho curricular da formação inicial de professores na província de Buenos Aires, em 1999 e 2017.

Palavras-chave: John Dewey. Abordagem comunicativa. Inglês como língua estrangeira. Formação docente.

\footnotetext{
1 Professora de Inglês em diferentes níveis e âmbitos na Argentina e Espanha. Cursa Mestrado em Educação com ênfase em Ciencias Sociais na Universidad Nacional del Centro, Argentina. E-mail: gabriellallaneza@yahoo.com.ar

${ }^{2}$ Doutora em Ciências da Educação pela Universidade Nacional de Córdoba (Argentina) e atua como professora na graduação e pós-graduação na Universidade Nacional do Centro da Província de Buenos Aires (UNCPBA) e Universidade Nacional de Rosário. E-mail: marisazelaya@gmail.com
} 


\title{
JOHN DEWEY'S INFLUENCE ON ELF TEACHING IN ARGENTINA
}

\begin{abstract}
In the present article, the autor identifies the main main ideas in John Dewey's educational philosophy, such as the learning experiences, the social construction of language as well as the relevance of active experimentation as part of the learning process to foster empowering and participatory attitudes for life. Despite the loose and biased interpretations in Argentina, the notions of pragmatic-experimentation were valued and implemented in institutions closer to the private education. Bilingual and private language schools have been foregoers in the use of English language teaching (EFL) methodologies within the Communicative Apporach, which are derived from social constructivisom, as proposed by Jerome Bruner, and Systemic Functional Linguistics (SFL), by M.A.K. Halliday, as well as fostering socio-pragmatic competence for multicultural interaction. As a contribution to the curriculum design in 1994-1995, 2007 y 2018, the communicative approach became the prescribed metoholodology for teaching EFL in all levels of education, including initial teacher training programs, as required in curriculum design for terciary level in Buenos Aires Province, 1999 and 2017.
\end{abstract}

Key words: John Dewey. English Language Teaching. Communicative approach. Teacher training

\section{LA INFLUENCIA DE JOHN DEWEY EN LA ENSEÑANZA Y FORMACIÓN DE PROFESORADO DE INGLÉS EN ARGENTINA}

En este breve trabajo se identificarán las características de la filosofía pedagógica Deweyniana, en relación al rol de la experiencia en el aprendizaje, la construcción social del lenguaje, y la importancia de la experimentación en los procesos de aprendizaje para una educación emancipadora y participativa. En Argentina los aportes del filósofo estadounidense incidieron de manera sesgada y fragmentada; sin embargo, las instituciones educativas cercanas al sector privado resultaron permeables a la filosofía pragmático-experimental. Tales instituciones privadas y colegios bilingües han marcado tendencia en la enseñanza de inglés como lengua extranjera al aplicar el enfoque comunicativo; el cual armoniza principios del constructivismo social, propuestos por Jerome Bruner, y lingüística sistémico-funcional (SFL), difundida por M.A.K. Halliday; y promover competencias socio-pragmáticas para la interaccion multicultural. Como parte de la reformulación de los diseños curriculares en 1994-1995, 2007 y 2018 el enfoque comunicativo se adoptó como metodología de la enseñanza de inglés como lengua extranjera y la formación inicial de profesores para en los diseños curriculares para el nivel en la provincia de Buenos Aires, en 1999 y 2017.

Palabras clave: John Dewey. Enfoque comunicativo. Ingles como lengua extranjera. Formación docente. 
Introdução

El estadounidense, John Dewey (1859-1952) fue uno de los filósofos de la educación más influyentes del siglo veinte, ya que sus obras constituyen la piedra angular del movimiento de la Educación Progresivista o "escuela Nueva", como se conociera en latino América; sus publicaciones redefinieron el rol de la educación en la construcción del 'ethos' democrático y la centralidad de la experiencia en desarrollo de los individuos como seres capaces de acrecentar sus habilidades y explorar su potencial al servicio del bien común. Su concepción revolucionaria de la escuela gira en torno a la necesidad de que estas instituciones no solo debían facilitar el aprendizaje de contenidos sino también preparar a los jóvenes para su desarrollo pleno y para la vida en sociedades participativas, democráticas y atravesadas por las contingencias de la industrialización, tecnologización y capitalismo corporativista.

Las teorías Deweyneanas, instancias del pensamiento proto-socio-constructivista, marcaron un camino de innovación en el pensamiento didáctico, al ofrecer una alternativa a la metodología positivista y promover el aprendizaje situado, experimental y significativo. Este impacto mundial de sus propuestas filosóficopedagógicas en la formación docente, evidencia cierto grado de heterogeneidad dependiendo del contexto socio-histórico de las culturas receptoras de sus ideas y/o traducciones, como de las disciplinas y/o niveles educativos. Mientras que, en Brasil, Anísio Teixeira, Fernando de Azevedo y Paulo Freire, promovieron y adaptaron las propuestas escolanovistas; en Argentina los aportes del filósofo estadounidense incidieron de manera sesgada y fragmentada tanto por su origen nacional como por su posicionamiento pro-democrático y laico, los cuales planteaban un conflicto con el posicionamiento positivista, espiritualista y oligárquico de las políticas educativas de nuestro país (CARUSO; DUSSEL, 2009). Sin embargo, las instituciones educativas cercanas al sector privado resultaron permeables a la filosofía pragmáticoexperimental, con propuestas metodológicas innovadoras en áreas como matemática, ciencias e idiomas. De la mano del constructivismo y el reposicionamiento de las didácticas especiales en las décadas de los años 70 y 80 , el modelo experimental comienza a implementarse en los niveles secundario, primario y universitario 
finalmente. En el contexto socio-político nacional, tanto las escuelas bilingües como los institutos de idiomas han gozado tradicionalmente de independencia de las políticas educativas y/o legislación respecto a lineamientos curriculares, por lo que históricamente han sido un contexto de ensayo y/o adopción de pedagogías foráneas o experimentales. En Argentina éstas instituciones han marcado tendencia en la enseñanza de inglés como lengua extranjera al aplicar el enfoque comunicativo; el cual armoniza principios del constructivismo social, propuestos por Jerome Bruner, y lingüística sistémico-funcional (SFL), difundida por M.A.K. Halliday; y promover competencias para la socialización multicultural, con clara influencia del pluralismo epistemológico escolanovista. Eventualmente, y como parte de la reformulación de los diseños curriculares para la educación primaria y media en 1994-1995, el enfoque comunicativo se adoptó como metodología de la enseñanza de inglés como lengua extranjera y eventualmente en la formación inicial de profesores para primaria y secundaria en los diseños curriculares para el nivel en la provincia de Buenos Aires, en 1999 y 2017 . En este breve trabajo se identificarán las características de la filosofía pedagógica Deweyniana, su relación con el enfoque comunicativo para la enseñanza de lenguas extrajeras (CLT) subyacente en los diseños curriculares para la enseñanza de inglés como lengua extranjera y formación de docentes de inglés en la provincia de Buenos Aires

Cada grupo humano que ha llegado a prosperar lo ha hecho a partir de la creación de formas cooperativas de construcción de un ideal, ciertas competencias socialmente valiosas y un sentido de pertenencia e identidad cultural que se codifican en los valores, lenguaje e instituciones de esa comunidad. Según Dewey (1966), en Democracy and Education (capitulo 1), las sociedades primitivas transferían estos valores y experiencias a los jóvenes informalmente y a través de rituales que marcaban la transición del infante al adulto socialmente responsable. No obstante, las sociedades con funciones altamente diferenciadas entre adultos y jóvenes han creado instituciones donde los niños/as pueden ser integrados paulatinamente a la cultura de forma progresiva y significativa. El acto pedagógico se constituye entonces en un acto político capaz de mediar entre el individuo y la cultura, en un largo proceso de descubrimiento y auto-descubrimiento, construcción, de-construcción y re- 
estructuración a medida que cada niño y joven se empodera, redefine y encuentra un lugar dentro de su sociedad.

En Estado Unidos, la educación pública, de la mano de la reforma de Horace Mann, en 1848, permitió expandir los valores republicanos, universalizar los saberes básicos y facilitar la movilidad social, ya fuera desde las áreas rurales a las urbanas o el ascenso social de los self-made men capaces de vivir el "Sueño Americano". La noción de libertad alimentaba así el individualismo: el desdén ante las restricciones sociales y la desatención de las tradiciones o el determinismo heredado. La filosofía transcendentalista "emersoniana" glorificaba la libertad íntima y la importancia de permanecer fieles sólo a la propia verdad. No obstante, el individualismo desmedido presentaría una contracara menos deseable en forma de egocentrismo o desidia por el bien común. Según Alexis Tocqueville en su descripción de la idiosincrasia estadounidense, "They entertain a presumptuous confidence in their own strength, and as they do not suppose that they can henceforward ever have occasion to claim the assistance of their fellow creatures, they do not scruple to show that they care for nobody but themselves" (TOCQUEVILLE, 1840, p. 5). Las consecuencias de tal grado de individualismo llegaron a evidenciarse en el siglo veinte cuando la sociedad estadounidense se viera plagada de ejemplos de corrupción, pobreza, desempleo, explotación, desigualdad, irresponsabilidad social y consumo desenfrenado socialmente aceptables, horrorizando a propios y a ajenos.

Es en este contexto que John Dewey problematiza el rol de la educación y redefine sus objetivos con el fin de atender a las necesidades de un contexto plagado de tecnología y contingencias que demandaban nuevos saberes, saberes que permitiesen no solo la prosperidad individual sino también la concreción de los ideales democráticos de su nación. Fuertemente influenciado por la filosofía pragmatista de William James, quien concibiera que las creencias pueden considerarse verdaderas cuando contribuyen a la supervivencia, individual o colectiva, y el orden social; Dewey entendió necesario redefinir la filosofía de la educación de modo que la escuela, como institución y sistema, transmitiera valores y concepciones conocimiento instrumentales para el individuo y la continuidad de la cultura o comunidad.

La propuesta de reforma de la educación progresivista codifica las preocupaciones el movimiento progresista y busca romper con el idealismo y realismo 
desde lo filosófico, alejarse del utilitarismo y darwinismo social, y redefinir el liberalismo político que habría resultado en el nativismo y capitalismo corporativista en Estados Unidos, a la vez que propone una alternativa al modelo de educación positivista y esencialista. En Democracy and Education: An Introduction to the Philosophy of Education Dewey (1966) objeta la postura Rousseauneana de la educación, al admitir que si bien es legítimo pensar que la sociedad limita a los individuos y efectivamente es necesario atender a los intereses e inclinaciones naturales del niño. Tal perspectiva no asegura la construcción de una sociedad libre y justa, sino que por el contrario permitió asemejar al niño con una tabula rasa en la que la verdad de la naturaliza armoniosamente se imprimiría a través de la experiencia, sin atender a la interrelación dinámica entre el individuo, la comunidad, el lenguaje y la construcción de la realidad que nace a través de la comunicación.

\begin{abstract}
Education in accord with nature was thought to be the first step in insuring this more social society. It was plainly seen that economic and political limitations were ultimately dependent upon limitations of thought and feeling. The first step in freeing men from external chains was to emancipate them from the internal chains of false beliefs and ideals. What was called social life, existing institutions, were too false and corrupt to be intrusted with this work [...]. To insist that mind is originally passive and empty was one way of glorifying the possibilities of education. If the mind was a wax tablet to be written upon by objects, there were no limits to the possibility of education by means of the natural environment. And since the natural world of objects is a scene of harmonious 'truth', this education would infallibly produce minds filled with the truth (DEWEY, 1966, p. 92-93).
\end{abstract}

El autor también observa la necesidad de extender un nuevo ideal de educación emancipadora, en una sociedad que al ampliar la participación de su base ciudadana requería un grado de organización que excedía a los individuos, por lo que los esfuerzos filantrópicos de la sociedad civil pronto requirieron la regulación de los estados nacionales, con lo cual la aspiración de individualismo cosmopolita transmutó en "ideal de ciudadano" nacional.

The realization of the new education destined to produce a new society was, after all, dependent upon the activities of existing states. 
The movement for the democratic idea inevitably became a movement for publicly conducted and administered schools. So far as Europe was concerned, the historic situation identified the movement for a state-supported education with the nationalistic movement in political life-a fact of incalculable significance for subsequent movements (DEWEY, 1966, p. 93).

Así, la supuesta universalización de la educación emancipadora pasó a ser reformulada en las manos de estados que se arrogaron la capacidad de definir el rol de cada individuo y las potencialidades a desarrollar en ellos. En este escenario la educación y la escuela funcionarían como dispositivo disciplinar en el que cada individuo subordinaba su singularidad a los intereses superiores del colectivo nacional ${ }^{3}$ (DEWEY, 1916). Dewey entendía que tales dicotomías habrían creado un extrañamiento entre la escuela y el entorno del niño, entre el saber y el aprender desde lo informal y lo formal, a tal punto que la educación escolar resultaba poco significativa o hasta exclusiva; por lo tanto, la escuela no estaría cumpliendo su misión respecto al individuo ni para con la sociedad.

\footnotetext{
3 "This change in practice necessarily brought about a change in theory. The individualistic theory receded into the background. The state furnished not only the instrumentalities of public education but also its goal. When the actual practice was such that the school system, from the elementary grades through the university faculties, supplied the patriotic citizen and soldier and the future state official and administrator and furnished the means for military, industrial, and political defense and expansion, it was impossible for theory not to emphasize the aim of social efficiency. And with the immense importance attached to the nationalistic state, surrounded by other competing and more or less hostile states, it was equally impossible to interpret social efficiency in terms of a vague cosmopolitan humanitarianism. Since the maintenance of a particular national sovereignty required subordination of individuals to the superior interests of the state both in military defense and in struggles for international supremacy in commerce, social efficiency was understood to imply a like subordination. The educational process was taken to be one of disciplinary training rather than of personal development. Since, however, the ideal of culture as complete development of personality persisted, educational philosophy attempted a reconciliation of the two ideas. The reconciliation took the form of the conception of the "organic" character of the state. The individual in his isolation is nothing; only in and through an absorption of the aims and meaning of organized institutions does he attain true personality. What appears to be his subordination to political authority and the demand for sacrifice of himself to the commands of his superiors is in reality but making his own the objective reason manifested in the state-the only way in which he can become truly rational. The notion of development which we have seen to be characteristic of institutional idealism (as in the Hegelian philosophy) was just such a deliberate effort to combine the two ideas of complete realization of personality and thoroughgoing 'disciplinary' subordination to existing institutions". (DEWEY, 1966, p. 94).
} 
[...] the school has been so set apart, so isolated from the ordinary conditions and motives of life, that the place where children are sent for discipline is the one place in the world where it is most difficult to get experience-the mother of all discipline worth the name. It is only where a narrow and fixed image of traditional school discipline dominates, that one is in any danger of overlooking that deeper and infinitely wider discipline that comes from having a part to do in constructive work, in contributing to a result which, social in spirit, is none the less obvious and tangible in form [...] (DEWEY, 1956, p. 17).

Lejos de considerar a la escuela como un contexto artificial, Dewey propone recuperar la centralidad de la experiencia en el proceso de aprendizaje. Para el autor cada niño nace con necesidades que solo pueden ser satisfechas dentro de un contexto social, la familia de la que depende para su subsistencia, y es por medio de sus impulsos y la respuesta del contexto físico y emocional que el infante estructura una comprensión rudimentaria de lo que es posible y aceptable, o no. Tales experiencias propician la creación de "hábitos", estructuras relativamente estables, que le permiten desenvolverse en su contexto social y físico. En este modelo proto-constructivista, se aprecia la dinámica de la experiencia y rol activo del individuo capaz experimentar sobre el mundo físico a medida que adopta "hábitos" flexibles, enraizados en su imaginación e ideas subjetivas, las tradiciones y experiencias ancestrales colectivas, que le permitirán eventualmente alterar su medio y contexto a partir de los desafíos que la comunidad enfrente. Al enfrentar dificultades en el medio, los hábitos se problematizan y los individuos deben aplicar sus capacidades para solucionar problemas y reflexionar de modo que la inteligencia se desarrolla mediante la actividad, la observación, la percepción, la comunicación, el aprendizaje y la actitud crítica, de tal forma que la inteligencia excede al individuo y se descubre en la interacción cooperativa con el medio y los otros. Dewey establece una distinción entre "hábitos' y "rutinas": los 'hábitos' se caracterizan por un nivel de flexibilidad que los hace permeables a ser de-construidos, gracias a la reflexión, y reconstruidos, a través de la interacción con nuevos problemas y experiencias; mientras que las "rutinas" serían "hábitos fosilizados" (GARRISON; NEWBERT; REICH, 2012).

Para Dewey (1916), existen dos tipos de experiencias: la experiencia primaria y la experiencia secundaria. La experiencia primaria se construye en el primer nivel de interacciones de los organismos en la naturaleza, entre los cuales se encuentran los 
humanos en interacción con todos quienes allí viven; para Dewey esta es la naturaleza en su forma elemental, contingente imprevisible, frágil e inesperada. Tal experiencia primaria surge de la interacción espontanea del infante con el medio, pero carece del elemento reflexivo. La experiencia secundaria implica una intelectualización de la situación problemática, que deviene en un aprendizaje o adaptación de los hábitos adquiridos, a fin de evitar consecuencias desagradables. Por ser los humanos inteligentes y capaces de desarrollar su pensamiento rudimentario y entonces, de prever las consecuencias de sus acciones (por la aplicación del metódico de la investigación) pueden ascender gradualmente a otro nivel de experiencia: la experiencia secundaria o reflexiva. En un contexto social, muchos de esos aprendizajes pueden ser comunicados al niño; no obstante, cuando la educación se basa solo en la mera apropiación e internalización de tales aprendizajes se produce una intelectualización indirecta que empobrece las capacidades del niño y lo distancia de las experiencias de la vida (GARRISON; NEWBERT; REICH, 2012). El rol de la escuela debería propiciar la experimentación e interacción del niño con su contexto, y facilitar la reflexión de modo que las experiencias se tornen significativas y valiosas, tanto para la construcción de "habitos" individuales como para la concientización de los mismos en el contexto de su cultura. Es por ello que la pedagogía Deweyniana, se focaliza en la identificación de problemas significativos para el niño y los procesos psicológicos y sociológicos que permitan su resolución.

I believe that this educational process has two sides - one psychological and one sociological; and that neither can be subordinated to the other or neglected without evil results following. Of these two sides, the psychological is the basis. The child's own instincts and powers furnish the material and give the starting point for all education. Save as the efforts of the educator connect with some activity which the child is carrying on of his own initiative independent of the educator, education becomes reduced to a pressure from without. It may, indeed, give certain external results but cannot truly be called educative. Without insight into the psychological structure and activities of the individual, the educative process will, therefore, be haphazard and arbitrary. If it chances to coincide with the child's activity it will get a leverage; if it does not, it will result in friction, or disintegration, or arrest of the child nature. (DEWEY, 1975, p. 85). 
En My Pedagogic Creed, Dewey (1975) sienta las bases de su propuesta pedagógica para una sociedad industrializada, y redescubre las potencialidades de las metodologías de entrenamiento profesional ${ }^{4}$, de modo que la educación permita a los jóvenes prepararse para el futuro, desarrollar de sus capacidades individuales y así insertarse social y laboralmente en función de sus intereses y aptitudes. Esta propuesta contempla la integración de la dimensión psicológica y social del acto pedagógico. El rol de la escuela es entonces ofrecer un contexto social simplificado, partiendo de la vida familiar y facilitando su eventual participación en activadas más complejas. En Schools of Tomorrow, Dewey e Dewey (2015) analiza las propuestas de Pestalozzi y Montessori, y observa que la complejidad de la realidad hace casi imposible la construcción de un currículo secuenciado, y la educación de los niños corre el riesgo de caer en el 'espontaneismo'. El rol del docente, no debería estar limitado a identificar los órdenes de adquisición naturales, ni exponer a los niños a tantas experiencias como fuera posible, sino en crear situaciones en las que la experimentación se vincule con las diferentes áreas del conocimiento de manera explícita.

Methods and materials must be used which are in themselves vital enough to represent to the child the whole of this compact nature which constitutes his world. [...]. In visiting schools the things that are interesting and helpful to the average school teacher are the methods, and the curriculum, the way the pupils spend their time; that is, the way the adjustment between the child and his environment is brought about (DEWEY, 2015, p. 29).

Su propuesta didáctica se resume en la frase "learning by doing" (aprender haciendo), ya que, según el autor, el conocimiento en los libros no podrá ayudar a resolver los problemas que se enfrenten en la práctica. Dewey nos recuerda que el conocimiento científico tal como lo conocemos no fue creado intencionalmente de manera organizada, sino consolidado a lo largo de generaciones; por lo que presentarlo como una acumulación cristalizada no hace más que socavar su aprendizaje. Ya que tanto los contenidos como las experiencias escolares deberían estar integrados, en su

\footnotetext{
4 “Apprenticeship traning”
} 
propuesta se trata de rescatar las experiencias de la vida diaria y enmarcarlas en el área disciplinar pertinente; así, la experiencia se transforma en la base del conocimiento consciente del área disciplinar propiciando una forma de enseñar progresiva (DEWEY, 2015).

Education which ignores this vital impulse furnished by the child is apt to be 'academic,' 'abstract,' in the bad sense of these words. If text-books are used as the sole material, the work is much harder for the teacher, for besides teaching everything herself she must constantly repress and cut off the impulses of the child towards action. Teaching becomes an external presentation lacking meaning and purpose as far as the child is concerned. Facts which are not led up to out of something which has previously occupied a significant place for its own sake in the child's life, are apt to be barren and dead (DEWEY, 2015, p. 30).

El modelo metodológico experimental propuesto por Dewey, constituye un punto de partida de la enseñanza basada en el alumno (learner-centered education), así como el aprendizaje situado (place-based education), el aprendizaje basado en proyectos (project-based learning) y el aprendizaje basado en resolución de problemas (problem-based education). En John Dewey's Philosophy of Education An Introduction and Recontextualization for Our Times (GARRISON; NEWBERT; REICH, 2012), los autores explican las cinco etapas del modelo propuesto por Dewey (1966) en Democracy and Education:

- La primera etapa de 'confusión' del pensamiento se caracteriza por la utilización irreflexiva de suposiciones que permiten identificar hechos y datos, ensayar hipótesis iniciales y/o posibles soluciones a partir de los conocimientos previos y hábitos para la resolución de problemas.

- La segunda etapa consiste en la 'intelectualización', en ésta etapa el pensamiento anoético da paso al abordaje cognitivo del problema, previo a la enunciación del mismo, ya que para el autor la capacidad de enunciar un problema implica una articulación de sus circunstancias, hechos e hipótesis iniciales. En esta etapa la propuesta de problemas reales para los alumnos hace posible la aplicación de los saberes previos en un contexto significativo, 
es por ello que Dewey insiste en rescatar problemáticas situadas vivenciadas por los alumnos en la vida extra-escolar y utilizar espacios de experimentación dentro del contexto escolar. En Democracy and Education, Chapter Twelve: "Thinking in Education", el autor sugiere,

Where schools are equipped with laboratories, shops, and gardens, where dramatizations, plays, and games are freely used, opportunities exist for reproducing situations of life, and for acquiring and applying information and ideas in the carrying forward of progressive experiences (DEWEY, 1966, p. 161-162).

En esta etapa el rol de docente es fundamental, ya que no se trata simplemente de proponer un problema, sino de acompañar y facilitar el acceso a la información necesaria para la intelectualización y formulación de hipótesis. La información puede provenir de diferentes fuentes, "It is a matter of indifference by what psychological means the subject matter for reflection is provided. Memory, observation, reading, communication, are all avenues for supplying data" (DEWEY apud GARRISON; NEWBERT; REICH, 2012, p.61). A la luz de las investigaciones en estilos de aprendizaje (OXFORD, 1990) e inteligencias múltiples (ARNOLD; FONSECA, 2004) en relación a la enseñanza de inglés, sería pertinente proponer medios alternativos, escritos, orales y multimedia, así como distintas configuraciones de trabajo: grupos, pares o individual, (MURRAY; CHRISTISON, 2011).

- La tercera etapa es la exploración de las consideraciones pertinentes al problema, e implica la capacidad de examinar, analizar y clarificar el problema. En esta instancia el lenguaje permite de-construir la situación a partir de la praxis.

- La cuarta etapa es la re-definición de hipótesis constatables dentro del universo de hechos. Esta es una instancia de pensamiento creativo y divergente, en la que no se trata de inventar nuevas posibilidades sino de transferir conocimientos adquiridos a una nueva situación. De este intento de explicación del fenómeno surge un plan de acción o una predicción de las consecuencias posibles. En la práctica áulica, el docente debería estar sumamente atento y proporcionar el andamiaje pertinente al estudiante, por 
medio de preguntas que guíen en la transferencia de conocimientos de un área o disciplina a otra, de modo que el recorrido cognitivo se haga habitual, y eventualmente autónomo.

- La quinta etapa requiere la aplicación de la hipótesis y su contrastación con la experiencia empírica, a fin de efectuar las acciones que resulten en las consecuencias anticipadas y sea posible constatar las hipótesis preliminares.

Este modelo recurrente permite la elaboración y construcción de verdades preliminares y constatables a través de la experimentación, lo cual redunda en la creación de conocimientos parciales susceptibles de ser ampliados, re-elaborados y sistematizados en reiteradas intervenciones. Ahora bien, dado que no es posible para un individuo experimentar en primera persona todas las situaciones posibles, y que muchas de las experiencias que conforman el acervo cultural y permiten la vida en comunidad forman parte de una inteligencia compartida y construida para una sociedad con fines y características particulares, el lenguaje y la comunicación tienen un rol central en la filosofía Deweyniana.

En Language Democracy and Education, Dewey (1966) propone una teoría del lenguaje como resultante de la cooperación y el uso en las comunidades, es decir que cada variedad lingüística sería una construcción social que atiende a las necesidades, historia e idiosincrasia de cada comunidad. Desde tal perspectiva la relación entre el significante y el significado solo puede ser comprendida a partir de la interacción, y ejemplifica:

When the mother is taking the infant out of doors, she says 'hat' as she puts something on the baby's head. Being taken out becomes an interest to the child; mother and child not only go out with each other physically, but both are concerned in the going out; they enjoy it in common. By conjunction with the other factors in activity the sound 'hat' soon gets the same meaning for the child that it has for the parent; it becomes a sign of the activity into which it enters. The bare fact that language consists of sounds which are mutually intelligible is enough of itself to show that its meaning depends upon connection with a shared experience (DEWEY, 1966, p. 15 ). 
En la concepción semiótica de Dewey, la imaginación y el lenguaje permiten al ser humano expandir su capacidad de experimentar e interpretar más allá de los límites de su contexto inmediato; el solo hecho de codificar una experiencia propia implicaría un extrañamiento y reposicionamiento en la mirada del otro, por lo que la propia experiencia es revivida y reconstruida desde la intersubjetividad.

\begin{abstract}
We conclude, accordingly, that the use of language to convey and acquire ideas is an extension and refinement of the principle that things gain meaning by being used in a shared experience or joint action; in no sense does it contravene that principle. When words do not enter as factors into a shared situation, either overtly or imaginatively, they operate as pure physical stimuli, not as having a meaning or intellectual value. They set activity running in a given groove, but there is no accompanying conscious purpose or meaning. (DEWEY, 1966, p. 16).
\end{abstract}

La propuesta pedagógica de Dewey propició el redescubrimiento de métodos de enseñanza originalmente asociados a la formación profesional: 'apprenticeship training'. W. Kilpatrick fue uno de los impulsores del 'aprendizaje por proyectos', y si bien esta forma de enseñar y aprender mejoraba visiblemente la construcción de aprendizajes significativos, los orígenes de la metodología suscitaban dudas sobre qué tipo de ciudadano se estaba formando, ya que se temía que al no asegurar unos conocimientos mínimos comunes propiciaría un empobrecimiento de la formación ciudadana. En la década de 1940 la pedagogía de Dewey se expandió en su versión más despolitizada, sin embargo, el enfoque pedagógico con su carácter intrínsecamente empoderador del individuo a través del trabajo cooperativo, desafiaba ideologías conservadoras.

Tal vez por este motivo, la formación docente en Argentina y otros lugares del mundo permaneció regida por una filosofía positivista que mantenía firmemente la dicotomía 'teoría- practica' y un enfoque didáctico predominantemente generalista que recién en la década de 1970 comenzó a ser cuestionada desde las didácticas disciplinares. En el campo de enseñanza de inglés como lengua extranjera (EFL), esta década está marcada por la ruptura con el conductismo, y la introducción de un abordaje humanista con métodos experimentales. En 1972, en su libro The Process of Education, el psicólogo norteamericano Jerome Bruner, propuso una teoría 
interaccionista del proceso de aprendizaje del lenguaje que revolucionaria el campo de la didáctica de las lenguas extranjeras. Su teoría del aprendizaje de las lenguas refutaba la hipótesis innatista de Chomsky, al proponer que la adquisición del código lingüístico es el resultado de la interacción del niño con adultos que adaptaban su uso del código para facilitar la comprensión; para Bruner el lenguaje tiene una función comunicativa con lo cual la dimensión semántica y pragmática serian esenciales.

En el campo de la enseñanza de lenguas extrajeras esta visión del aprendizaje propició una ruptura con los modelos estructuralistas y innatistas. Y los estudiantes dejaron el rol pasivo del método audio-lingüístico y el método naturalista; a partir de ese momento los estudiantes comenzaron a ser vistos como participantes activos en la negociación de significado. Los esquemas cognitivos, las expectativas y las estrategias de procesamiento de la información reconfiguraron las complejidades de la comunicación interactiva, dentro y fuera del espacio áulico en la que los hablantes no solo aprendían estructuras, vocabulario y sonidos, sino que se percibían capaces de recrear códigos estratégicamente para facilitar su participación de modo significativo. Como consecuencia surge el enfoque comunicativo (CLT), en el que la finalidad del aprendizaje de la lengua extranjera ya no era la imitación camaleónica del hablante nativo del idioma anglosajón, sino el talento para la interpretación, expresión y negociación que evidenciaran un grado inteligible de competencia comunicativa.

El enfoque comunicativo se origina casi paralelamente en Estados Unidos y Europa, con nuevas teorías del lenguaje que completan la teoría del aprendizaje de Dewey y Bruner. Hymes (1971) propuso el término 'competencia comunicativa' para definir el uso del lenguaje en contextos sociales, o la observancia de normas sociolingüísticas de pertinencia; su preocupación con las comunidades discursivas, y la interrelación del lenguaje, la comunicación y la cultura no eran diferentes a las de Halliday (1978). Según Halliday, el lenguaje es un sistema semiótico capaz de codificar significados simultáneos: ideacional (el contenido), textual (cohesión y coherencia entre las diferentes partes del discurso) e interaccional (crear o mantener relaciones entre los participantes); por lo tanto, el contexto situacional, histórico y cultural determinan las elecciones del hablante dentro del repertorio lingüístico compartido en la interacción. Tales significados coexisten en el discurso oral y escrito, codificando mucho más que la información que los usuarios de la lengua apuntan a intercambiar, 
sino también su historia compartida, valores culturales, e intenciones. En el marco de la Lingüística Sistémico-funcional, el estudio de las lenguas extranjeras se enfoca en el aspecto funcional del lenguaje. Estas funciones (también llamados "actos del habla") son los propósitos que se intenta concretar con el uso del lenguaje, esto impuso un cambio de paradigma en la secuenciación y análisis del discurso, pasamos a la etapa del análisis de texto (oral y escrito) como respuesta contextualizada a una situación retórica (EGGINS, 2005). Por su parte, Savignon (2001) introdujo el término 'competencia comunicativa' para definir la habilidad de los aprendices del idioma para interactuar con otros hablantes como diferente a habilidad para producir oraciones gramaticalmente correctas (CELCE-MURCIA, 2001). Esta re-conceptualización del término daría paso a la descripción de objetivos de aprendizaje como repertorio de sub-competencias, con énfasis en la inteligibilidad y la capacidad de cooperar más allá de la corrección lingüística. Desde esta perspectiva, para concretar propósitos comunicativos eficazmente, en sus futuros campos laborales y académicos, tradicionalmente se considera necesario que los estudiantes de la lengua extranjera adquieran cierto grado "competencia comunicativa" (CANALE; SWAINE, 1980), concepto que Lyle Bachman (1990) redefine como "competencia lingüística", dentro de la cual podemos identificar sub-competencias: gramatical, discursiva, estratégica y sociocultural (BROWN, 2006).

En el plano didáctico-metodológico, el enfoque comunicativo (CLT), se caracteriza por su flexibilidad y eclecticismo, ya que no prescribe un lineamiento didáctico, sino principios generales y objetivos en forma de competencias y subcompetencias deseables, que pueden ajustarse a los fines específicos de los estudiantes del idioma. A lo largo de su historia pueden diferenciarse diferentes estadios: el enfoque comunicativo duro (en el cual el rol del docente es exponer al estudiante a situaciones comunicativas y facilitar frases o palabras que puedan resultar útiles, sin interponer una estructura gramatical sino temática en la progresión de actividades), una rama blanda (en la que la corrección lingüística es tenida en cuenta y el docente se vale del razonamiento inductivo para propiciar la familiarización e internalización de estructuras) y un una rama que integra contenido y lenguaje o 'content-based' (en la que el lenguaje es presentado en el textos o situaciones 
relacionados a la temática escolar, laboral o cultural, y se espera que el estudiante active estrategias y conocimientos previos como andamiaje para la comprensión, y reestructuración de su conocimiento lingüístico de la lengua meta de forma contextualizada). Estas posturas han dado lugar a diferentes principios organizadores en la construcción del currículo en la enseñanza de inglés como lengua extranjera, tanto en Argentina como en otros países.

Durante las décadas de 1970 y 1980, en nuestro país la postura que integraba situaciones comunicativas y estructuras lingüísticas comenzó a abrirse paso, en contextos de enseñanza menos regulados tales como institutos de inglés, escuelas bilingües o privadas. En la provincia de Buenos Aires, como en el resto del territorio nacional la enseñanza de las lenguas extranjeras era obligatoria solo para el nivel secundario, y permitía la opción de inglés, francés, italiano; por lo que la formación de profesores de inglés como lengua extranjera no era una prioridad provincial ${ }^{5}$. La Ley Federal de Educación (24.195/94) restructuró el sistema de educación primaria y secundaria, e introdujo como requisito obligatorio la enseñanza de una lengua extranjera desde el 4to año de la Educación General Básica, hasta el 6to año de la Educación Polimodal. Dentro de esta reforma la lengua extranjera se consideraba un capital para la inserción en el mundo globalizado, por lo que la metodología de enseñanza propuesta era el enfoque comunicativo.

El aprendizaje de lenguas extranjeras ayuda a reflexionar sobre los procesos que generan la propia lengua; abre el espíritu hacia otras culturas y hacia la comprensión de los otros, y brinda una cosmovisión más amplia del mundo en su diversidad. La capacidad de funcionar con otros códigos lingüísticos propicia una estructura mental más diversificada; un pensamiento más flexible, suscita un mayor desarrollo de las capacidades intelectuales superiores y una mejor aplicación del propio código lingüístico. El inglés como lengua de comunicación internacional cumple un rol fundamental en este campo a partir de su pertinencia como espacio de encuentro habitual entre hablantes de lenguas diferentes para facilitar la comunicación social, científica o técnica. Adopta rasgos de inteligibilidad general, es decir aquéllos no asociados con ninguna variedad o cultura de origen

\footnotetext{
${ }^{5}$ Dado que pocas universidades ofrecían títulos como profesores y los institutos superiores prestigiosos se encontraban en, en las provincias, como Provincia de Buenos Aires, el nomenclador de Dirección General de Escuelas contemplaba el certificado de la Asociación Argentina de Cultura Ingles (AACl), Adults Senior 6 como certificado bonificante, lo que en la práctica implicaba que cualquier docente egresado/a de una Escuela Normal que tuviera ese certificado pasaba a ser parte del nomenclador para cargos docentes, y podía dictar clases tanto en el nivel primario como secundario.
} 
particular, facilitando, sin embargo, la entrada a muchas culturas (CONSEJO FEDERAL DE CULTURA Y EDUCACIÓN, 1998).

La creación de las carreras de formación inicial de Profesorado de Ingles para EGB y Educación Polimodal (1999) como parte de la oferta en los institutos superiores de formación docente (ISFD) apuntaba a formar docentes para los niveles anteriores. Esto implicaba una ruptura con los paradigmas de formación docente orientados a métodos de enseñanza de la lengua extranjera tradicionales tales como el Grammar Translation Method (usado desde el siglo XIX para facilitar la traducción) o el Audiolingual Method (basado en el conductismo, propone la formación de "hábitos lingüísticos" a partir de la repetición sistemática), por lo que recién a partir de 2000, se empieza a instaurar fuertemente la integración de contenido lingüístico con contenido disciplinar a través de Task-based learning Instruction (TBL), Genre-based Learning Instruction, Project-based Larning Instruction (PBL) y más recientemente en los diseños curriculares jurisdiccionales para educación primaria (2008/2018) secundaria (2007) y formación docente (2017) Content and Language Integrated Learning (CLIL) y Problem-based Learning (PBL).

Estas metodologías de la enseñanza del inglés como lengua extranjera, instan el aprendizaje del contenido lingüístico a partir materiales auténticos y de situaciones comunicativas cercanas a la experiencia de los estudiantes según sus conocimientos y contextos reales, ya sean presentes o futuros, de modo que se facilite la transferencia del aprendizaje a situaciones extra-áulicas. Los juegos, dramatizaciones, producciones, actividades de autodescubrimiento, selección de información y análisis de ejemplos activan las estrategias de aprendizaje y promueven el desarrollo de competencias lingüísticas, socio-pragmáticas, y la sensibilización cultural necesarias para la negociación de significados en contextos multiculturales (HINKEL, 2001). Lejos de promover la aculturación y el imperialismo cultural, recelado por décadas en Argentina, el aprendizaje de otras lenguas dentro del enfoque comunicativo, y en particular a partir de la integración de la perspectiva intercultural, facilita el desarrollo de individuos autónomos, y críticos respecto a los valores e instituciones de la cultura propia y foránea, lo cual es claramente un atributo esencial para re-crear una sociedad 
democrática en el contexto de un mundo cada vez más integrado, globalizado y atravesado por la tecnología.

En sintonía con esta perspectiva la formación de docentes de Educación Primaria y Secundaria se sostiene en los enfoques influenciados por la filosofía de Dewey,

c) Estrategias de enseñanza que hagan foco en un papel central del estudiante y en el desarrollo de capacidades: Estrategias que ponen el centro en el estudiante/futuro profesor, tales como el estudio de casos, la enseñanza basada en problemas, la enseñanza centrada en proyectos, el aprendizaje cooperativo, entre otras, se tornan fundamentales en la formación de los profesores. Estas propuestas que buscan desafiar a los estudiantes privilegian el abordaje de problemáticas estrechamente relacionadas con la práctica real. En consonancia, resulta fundamental que el diseño de la evaluación de los aprendizajes sea coherente y pertinente con las propuestas de enseñanza, los propósitos y contenidos planteados. Se propone una noción de evaluación formativa e integradora. En este sentido, desde el rol docente, se busca brindar información acerca del estado de aprendizaje de cada estudiante, a través de la retroalimentación, buscando ayudar a la mejora del proceso de aprendizaje (BUENOS AIRES, 2017, p. 13).

Por su parte la inclusión de espacios tales como Estudios Interculturales en lengua inglesa, Literatura en lengua inglesa y niñez o Literatura en lengua inglesa y juventud dan cuenta de la integración de lenguaje-contenido-cultura propuesto para los niveles primario y secundario. En propósitos y contenidos del espacio curricular Fundamentos de la Enseñanza y Aprendizaje del Inglés I, II y III también se insta a la formación de docentes capaces de propiciar formas de aprendizaje basados en la colaboración y experimentación:

- Favorecer la reflexión sobre el propio proceso de adquisición de la lenguamaterna, y su proceso de adquisición y aprendizaje del idioma inglés.

- Concientizar a los futuros docentes acerca de la relevancia de la enseñanza de la lengua inglesa como práctica social.

- Posibilitar la apropiación de herramientas conceptuales que orienten la planificación de actividades de clase centradas en el alumno, para el desarrollo de la competencia comunicativa (BUENOS AIRES, 2017, p. 89). 
Enseñanza centrada en el alumno. Enseñanza cooperativa y colaborativa. Enfoque CLIL. Las cuatro C. Las habilidades del siglo XXI. Los proyectos interdisciplinares con otras áreas curriculares. Enfoque AICLE. Enfoque basado en tareas. El desarrollo del aprendizaje autónomo. El desarrollo de habilidades de aprendizaje: análisis y pensamiento crítico. El contenido temático como hilo conductor. Los recursos didácticos. Adaptación de materiales auténticos y semiauténticos según el propósito de uso. (BUENOS AIRES, 2017, p. 98).

La influencia escolanovista está claramente plasmada no solo en las metodologías de enseñanza de inglés que los docentes de inglés deberían ser capaces de implementar sino en la perspectiva pedagógica respecto a la formación docente, a la que el diseño curricular para el Profesorado de inglés, 2017, suscribe:

[...] se parte del supuesto de que la formación de los docentes implica generar las condiciones para que los/las estudiantes realicen un trayecto que les permita reconocer y comprometerse en un proceso permanente y continuo de su desarrollo profesional, y en esto la formación inicial tiene un peso sustantivo: supone un tiempo y un espacio de construcción personal y colectiva donde se configuran núcleos de pensamiento, conocimientos y prácticas. Dicho proceso debe generar condiciones para el ejercicio de la responsabilidad y supone oportunidades de elección y creación en un clima de compromiso compartido (BUENOS AIRES, 2017, p. 10).

\section{Conclusão}

En conclusión, John Dewey vivió e interpretó las desigualdades sociales producto de la industrialización, y el capitalismo corporativo en los albores del siglo veinte, y propuso una perspectiva sociocultural del conocimiento y el aprendizaje, al asumir que el conocimiento y la inteligencia humanos se construyen a través de la participación en actividades sociales, y que son las relaciones sociales y los materiales, signos y símbolos, artefactos semióticos, los que median esas relaciones y crean formas de conocimiento colectivo humano de alto-nivel intelectual. El desarrollo cognitivo del individuo es un proceso interactivo, mediado por la cultural, el contexto, el leguaje y la interacción social, e internalizado a través de la experiencia del mundo en un contexto cultural. Para Dewey el lenguaje, y la imaginación eran fundamentales para la participación del mayor número de individuos posibles en una comunidad, a fin que los intereses, necesidades y conocimientos de todos pudieran ser entendidos, compartidos 
e integrados en la creación de una sociedad democrática y justa en la que cada uno fuera capaz de encontrar su lugar y desarrollarse según su propio potencial.

Las nuevas formas de relación y comunicación propiciadas por las nuevas tecnologías invitan a revisitar la perspectiva intercultural y sociocultural del aprendizaje, en este caso de las lenguas. Tanto en nuestro país como en cualquier lugar del mundo globalizado, la capacidad de interactuar en una lengua extranjera resulta un instrumento innegable para la participación y el entendimiento entre individuos y culturas diferentes, sentando las bases para una sociedad democrática. Por motivos que exceden el alcance de este trabajo, el idioma inglés se ha constituido en una lengua franca a nivel internacional, aproximadamente un tercio de la población mundial que usa este idioma como lengua franca (LFE) o inglés como idioma internacional (EIL) o ingles global (EGL), lo han aprendido como segunda lengua o lengua extranjera, muchas veces de manera autónoma o informal y lo hacen por conveniencia y comodidad para entenderse con otros usuarios no nativos del idioma (CANAGARAJAH, 2007; JENKINS, 2015). La integración de pedagogías empoderadoras y participativas en la formación docente no hacen sino fortalecer los valores democráticos indispensables para crear sociedades más cercanas al meliorismo propuesto por John Dewey.

\section{Referências}

ARNOLD, J.; FONSECA, M. C. Multiple intelligence theory and foreign language learning: a brain-based perspective. International Journal of English Studies, Murcia, v. 4, p. 119136. 2004. Disponible:

https://digitum.um.es/jspui/bitstream/10201/2172/1/919582.pdf Acceso en: 4 abr. 2020.

Bachman, L. Fundamental considerations in language testing. Oxford: Oxford University Press, 1990.

BUENOS AIRES. Dirección General de Cultura y Educación. Dirección Provincial de Educación Superior. Profesorado de inglés. La Plata: Dirección General de Cultura y Educación, 2017. Disponible en: https://isfd52-bue.infd.edu.ar/sitio/nuevo-disenocurricular-profesorado-de-ingles-2018/upload/anexo_disen_o_ingles.pdf Acceso en: 4 abr. 2020.

BROWN, D. Principles of language learning and teaching. 5th ed. New York: Pearson ESL, 2006. 
BRUNER, J. The process of education. Cambridge: Harvard University Press, 1972.

CANAGARAJAH, S. Lingua franca English, multicultural communities and language acquisition. The Modern Language Journal, Madison, v. 91, p. 923-939, 2007.

CANALE, M.; SWAIN, M. Theoretical bases of communicative approaches to second language teaching and testing. Applied Linguistics, Oxford, v. 1, n. 1, p. 1-47, 1980. Disponible: https://es.scribd.com/doc/239755533/Canale-Swain-1980-TheoreticalBases-of-Communicative-Approaches-of-Second-Language-Teaching-and-Testing Acceso en: 4 abr. 2020.

CARUSO, M.; DUSSEL, I. Dewey en Argentina (1916-1946): tradición, intención y situación en la producción de una lectura selectiva. Encuentros sobre Educación, [Washington], v. 10, p. 23-41, 2009.

CELCE-MURCIA, M. Language teaching approaches: an overview. En: CELCE-MURCIA, M. Teaching english as a second or foreign language. 3rd. ed. United States: Heinle \& Heinle, 2001. p. 3-11

CONSEJO FEDERAL DE CULTURA Y EDUCACIÓN. Acuerdo marco para la Enseñanza de Lenguas. 7 mayo 1998. Disponible en:

http://www.bnm.me.gov.ar/giga1/documentos/EL000478.pdf Acceso en: 4 abr. 2020.

Dewey, J. Democracy and Education, 2016. Retrieved on April 2020, from: https://www.gutenberg.org/files/852/852-h/852-h.htm

DEWEY, J. The school and society. Chicago: The University of Chicago Press, 1956.

DEWEY, J. Democracy and education. New York: The Free Press, 1966.

DEWEY, J. My pedagogic creed. In: Journal of the National Education Association, Vol. 18, Nro 9, pp. 291-295. December 1929

DEWEY, E. Schools of tomorrow. New York: E.P. Dutton \& Company, 2015. E-book.

EGGINS, S. Introduction to systemic functional linguistics. 2nd ed. New York: Bloomsbury Publishing, 2005.

GARRISON, J.; NEWBERT, S.; REICH, K. John Dewey's philosophy of education: an introduction and recontextualization for our times. New York: Pelgrave-Macmillan, 2012.

HALLIDAY, M. A. K. Language as social semiotic: the social interpretation of language and meaning. London: Edward Arnold, 1978.

HINKEL, E. Building awareness and practical skills to facilitate cross-cultural communication. En: CELCE-MURCIA, M. Teaching english as a second or foreign language. 3rd ed. United States: Heinle \& Heinle, 2001. p. 243-258 
HYMES, D. Competence and performance in linguistic theory: acquisition of languages: models and methods. New York: Academic Press, 1971.

JENKINS, J. World englishes: a resource book for students. 3rd ed. Abingdon: Routledge, 2015.

MURRAY, E.; CHRISTISON, M. A. What english language teachers need to know. New York: Routledge, 2011.

Oxford, R. Language learning strategies: what every teacher should know. Boston: Heinle-ELT, 1990.

SAVIGNON, S. Communicative langauge teaching for the twenty-first century. En: CELCE-MURCIA, M. Teaching english as a second or foreign language. 3rd ed. United States: Heinle \& Heinle, 2001. p. 13-28

TOCQUEVILLE, A. Individualism stronger at the close of a democratic revolution than at other periods. En: TOCQUEVILLE, A. Democracy in America. [S. I.: s. n.], 1840. Book 2. Disponible en: https://marxists.architexturez.net/reference/archive/detocqueville/democracyamerica/ch27.htm Acceso en: 4 abr. 2020. 